International Journal of Engineering \& Technology, $7(2.29)(2018) 196-202$
International Journal of Engineering \& Technology
SPC
Website: www.sciencepubco.com/index.php/IJET
Research paper

\title{
Evolution of Malaysia's technology transfer model facilitated by national policies
}

\author{
Abdul Rahman Hamdan*, Mohamad Syazli Fathi, Zainai Mohamed \\ Razak School of Engineering and Advanced Technology, Universiti Teknologi Malaysia (UTM) \\ *Corresponding author E-mail: rahmanhamdan@gmail.com
}

\begin{abstract}
The government of Malaysia has introduced several national policies to facilitate industrialisation and technology development in the country throughout the years. However, the effectiveness of this policy in facilitating technology transfer has never be measured quantitatively. The objective of this paper is to review the evolution of Malaysia's technology transfer model and process since Malaysia gained its independence. This paper will look into the past and current national policies that have facilitated the technology transfer process in the country. A literature review was conducted on various frequently used technology transfer model since 1940s and compare it to the technology transfer process evolution in the country. From the analysis, the national policies introduced over the years have a direct and indirect effect on the technology transfer process in the country. However, the effectiveness of technology transfer model that was facilitated by the policy was never measured quantitatively. Further study needs to be conducted in measuring the efficiency of the technology transfer process that facilitated by a specific policy introduced by the government. The factors and sub-factors affecting the technology transfer process facilitated by this specific policy also need to be identified so that further improvement can be proposed.
\end{abstract}

Keywords: Technology Transfer; Technology Transfer Model; Government's Policy; Industrialization

\section{Introduction}

Technology transfer process is certainly not something new. Technology transfer was already happening during the Neolithic era when human started to develop technology (1). History has shown throughout the history that the technology transfer has occurred between civilisations and countries across the world. It is evident in the past that the Islamic civilisation in the Arabic world played a critical role regarding technology transfer from the East to West during the early century (1). In this particular of time, the Arabs are leading regarding scientific knowledge and therefore provide the technology and knowledge transfer to the West. The American industrial revolution in the $19^{\text {th }}$ century has resulted from a technology transfer of English textile expertise during the $18^{\text {th }}$ century $(2,3)$. The Japanese economic revolution after World War 2 has also resulted from a technology and knowledge transfer in the area of quality management from Edwards Deming of the United States to Japan (4). Toyota Corporation adopted this technology transfer and went to become a giant global automotive car maker until today.

In Malaysia, technology transfer has been used as a mean to develop the country from a developing country status to a developed nation. Technology transfer was used as leverage for Malaysia to participate in high value added activities. Among national projects that leverage technology transfer was the development of the automotive industry in Malaysia. The automotive industry in Malaysia has been jump-start through the technology transfer from Mitsubishi Motor Corporation (MMC) to Perusahaan Otomobil Nasional Sdn. Bhd. (PROTON) back in the early 1980s through government's initiatives (5). The technology transfer from MMC to PROTON was used as leverage to develop the heavy industries in Malaysia. However, in a certain sector such as the rail industry in Malaysia, the local industry are still very much dependent on foreign Original Equipment Manufacturers (6)(6)(6)(MIGHT,
$2014)^{6}$ with very limited key technology has been absorbed and transferred to the local rail industry (6). This occurrence is due to the lack of proper monitoring of technology transfer process during the development of the rail project.

\subsection{Definition of Technology Transfer}

Technology transfer has been described and deliberated in many studies and journals. Technology transfer can be defined as planned acquisition of technological knowledge and technique (7). Technology transfer is not just acquisition of knowledge but as well as the transfer of all types of knowledge relating to the field such as design, process, material use and also equipment utilisation (8). The study further stated that technology transfer is when a transferor or a foreign party made a transfer plan to a transferee or host party that arranged to receive the technology (8). Technology transfer can also be described as a process of knowledge transfer from a provider to a recipient. The meaning of 'transfer' in a technology transfer is the knowledge flows from its primary source to the secondary holder (9). Technology transfer can also be defined as when the process has achieved the introduction of new techniques, improvement of existing techniques and also the generation of new knowledge (10).

\section{Literature Review}

A literature review was conducted on the evolution of technology transfer model since 1940s to post 2000. A review was also done on relevant national policies that have a direct and indirect effect on the development of technology in Malaysia. The national policies selected are mainly policies that are formulated for the development of industries in Malaysia specifically on the upgrading of technology and local capability. Below are the key findings of the review that have been conducted. 


\subsection{Introduction}

During the postwar period from the late 1940s to the early 1960s, many countries are freeing themselves from colonialization and became independent countries. These newly independent countries choose different strategies regarding technology transfer to accelerate their development post-colonization (11). During 1945 to 1950s, the concept of technology transfer was only limited to search and transfer. The technology transfer process is very much linear with the concept that quality technologies can sell themselves (12). A proper framework to govern and monitor the technology transfer process was not emphasised at that time.

Once a country regain independence, the country either adopted the Import-Substitution Industrialization, Export-Oriented Industrialization or a combination of both (11). Akubue (2002) further stated in his study that third world countries adopted a massive but passive importation of technology. Innovations without modifications led the third world country to continuously rely on foreign technology providers in maintaining the new technology.

As a developing country further progress, most of the developing country realised the need for technology for the development of their economic purposes. However, some study has shown that some of the developing countries did not have effective policies in place to encourage technology transfer (13). Malaysia has been fortunate enough to have visionary leaders who have formulated specific policies over the years to encourage technology transfer. However, the effectiveness of this policies to encourage technology transfer have yet to be determined.

\subsection{Technology Transfer Model}

There are many technology transfer model that has developed throughout the years. These are some of the popular and most cited technology transfer models during a certain period.

During the early 1940s, technology transfer was viewed as a simple linear process. One of the technology transfer model developed during this time was the "Appropriability Model". The Model was developed during 1945 to 1950 s where it focuses on the quality of the technology itself and technology transfer will happen once it is exposed to competitive market pressure (12). This model suggests that there is no need for proper technology transfer mechanism to drive the process. It will simply happen once a good technology or research is found by a user or company (12).

As technology transfer models were further studied, the "Dissemination Model" was developed in 1960 to 1970s where it emphasised on the diffusion of technology and knowledge to the users by the experts. The model suggests that once a linka'ge has been created between an expert and a potential user, the technology and knowledge will flow (14). This model emphasises the important role of the expert that act as the transferor in disseminating the knowledge to a recipient. A dissemination model is similar to a teacher and student environment. The classroom where the teacher and students are located is the linkage that established the relationship between the expert and the potential users.

Technology transfer model was further enhanced in the late 1980s, where the "Knowledge Utilization Model" was first introduced where it focuses on the proper communication and mechanism of technology transfer (12). The model also takes into account the facilitation method and barriers to technology transfer. The limitation of this model is that it only describes technology transfer process as a linear process of technology exchanging from one party to another. A linear technology transfer model may not include external factors into accounts such as market force or government's policy (15)

In the early $1990 \mathrm{~s}$, more complicated technology transfer mode has been developed due to the emergence of knowledge based economy. One popular model was the "Interrelationship Model". This type of technology transfer model emphasises on the technology transfer between inter-firm and strategic alliances that often have complex relationship and structure (16). This model also acknowledges the true nature of technology transfer process that it is a nonlinear process.

Studies on technology transfer in the year post-2000 have greatly emphasised on the complex nature of the technology transfer environment. Some study even stated that the linear process of technology transfer is no longer relevant in today's age (17). One of the models developed was the "Role Shifting Model" (18). This model focuses on the innovation that comes out of the technology transfer process. The recipients of the technology will shift its role to a technology provider as a result of innovation in the technology (18).

\subsection{Malaysia's National Policy in Facilitating Technol- ogy Transfer}

Malaysia has formulated many policies over the years with the objectives of making the country a developed nation status by 2020. Even though there is no specific policy on technology transfer, there are emphasis and segmentation given on technology transfer in some of the government's policies. In this section, a review has been conducted to see whether the Malaysian government's past and present policy on industrialisation has facilitated technology transfer process in the country.

\subsubsection{Import-Substituting Industrialization Policy (The early 1960s)}

After independence, Malaysia's government have actively sought for industrialisation growth for the country. As one of the ways to accelerate and promote industrialisation, Malaysia has adopted the Import-Substituting Industrialization Policy (19). The strategy was to encourage foreign companies to set up production here in Malaysia to supply finished products previously imported from foreign countries. The Import-Substituting Industrialization policy strategy paved the way to Foreign Direct Investments in Malaysia. It was more focus on creating employment as well as attracting capital to flow into the country. Developing countries welcomes Foreign Direct Investment as it will normally bring also the transfer of technology, specialised knowledge, management know-how and also capital (13). The type of technology transfer process that arises from this policy falls under the Dissemination Model. In this model, it was under the presumption that new technology will be transferred from the expert to the non-expert as soon as a proper linkage has been established (14).

Therefore, it was assumed and expected that the ImportSubstitution policy that encouraged foreign companies to open their production here will automatically pave the way for technology transfer to local industries through local employment. However, as the findings by Osman-Rani and Piei, (20), the ImportSubstituting Industrialization policy have created distortions in domestic product prices, poor linkage effects with the rest of the economy and inequalities in income and employment. The weakness in this policy was that it only encouraged foreign companies to open their production factory here but without the proper requirement of technology transfer. Therefore, the technology transfer occurred very minimally with low value added activities.

\subsubsection{Export-Oriented Industrialization (EOI) Poli- cy (The late 1960s to 2000)}

With the introduction of the Import-Substituting Industrialization policy in the 1960s, it did not accelerate the industrialisation in Malaysia as it was hoped to be by the Government at that time. It also worsened the unemployment figures in Malaysia. The national unemployment figure stands at eight percent with Penang registered the highest unemployment with 15.2 percent (21). Malaysia then introduced the Export-Oriented Industrialization (EOI) Policy in the late 1960s to displace the Import-Substituting Industrialization Policy. Malaysia then introduced the Free Trade Zone Act of 1971 to spur the development of Free Trade Zone areas in the country. Among the first Free Trade Zone area was the Free Trade 
Zone in Bayan Lepas, Penang in 1972. By 1987, Malaysia has ten Free Trade Zone areas located in Penang, Selangor, Malacca, and Johore (21).

The early gaps of Free Trade Zone regarding technology transfer were that the foreign companies that have invested in Free Trade Zone areas offer low value added labour intensive production (21) Therefore, even with the change of policy by the government to spur industrialisation, technology transfer in Malaysia still resembles the process as in the Dissemination Model. There was no concrete mechanism to monitor and ensure high value added technology transfer from the foreign companies established in the Free Trade Zones to the local industries. The focus of that time is more towards employment creation and an increase of economic activities only.

However, after several years of the Multinational companies operating in Free Trade Zones, there was an increase of trends in the participation of local people to the management role and decision making in the Multinational companies (21). The practice of increasing the involvement of local people increased in the 1990s with our local engineers started to participate in the research and design of some of the Multinational companies operating in this Free Trade Zone (21). This trend directly increased the value added knowledge in the technology transfer process from low value added to high value added activities. Therefore, it can be said that the Free Trade Zone approach did somewhat contribute to a successful technology transfer from a foreign domain to a local environment. However, the process was linear and took a long time for the transition to occur.

The technology transfer model, however, has evolved from Dissemination Model to a Knowledge Utilization Model. The knowledge Utilization Model that was developed in the late 1980s (12) presumed that technology moves "hand-to-hand" to one direction, unilaterally from the experts to the users and eventually become a developed idea or product (12). The Knowledge Utilization Model in Malaysia's case occurred unilaterally from foreign experts who initially employed the local labour for labour intensive operation. The Multinational companies then train them over the years for them to be able to move up to management and also be involved in the design activities.

\subsubsection{Look East Policy (The early 1980s to 2000)}

Tun Dr Mahathir first announced The Look East Policy during his premiership on $8^{\text {th }}$ February 1982. In the Look East Policy, the Malaysian government has taken Japan as the benchmarking country and model regarding positive aspects of Japanese soft technology, work organisation and management styles (22). The Look East Policy has led to major Japanese investments in Malaysia in sectors such as Chemicals and pharmaceuticals, manufacturing, iron and steel, information technology, retail, finance and food industries (23).

The policy also gave birth to Malaysia's first national car maker, PROTON from the joint-venture between Heavy Industries Corporation of Malaysia and Mitsubishi Corporation from Japan. The technology transfer model adopted in this partnership evolved from a Knowledge Utilization model to an advanced Role Shifting model. It is evident in which PROTON that started as a recipient of technology has now become a full-fledged Original Equipment Manufacturer that can create their technology. As Choi (18) stated that the role shifting model generates innovations with the current recipients innovate and becomes the future technology provider.

\subsubsection{Science \& Technology Policy (The late 1980s to current)}

The Science and Technology Policy was formulated first in 1986 as a means to use science and technology as a catalyst for economic growth. The policy was followed by the "Industrial Technology Development: A National Action Plan" in 1990. Later, the second "National Science and Technology Policy" and "Plan of Action" was developed in 2002 (24). The Science and Technology policy includes the introduction to several programs that are implemented with the objective of enhancement of our research and development, increasing commercialisation and also developing new knowledge based industries among others. Based on the current policy, the technology transfer process is supported through strategic thrust outlined in the policy specifically on developing talent in the country as well as enhancing strategic international alliances (24).

One of the results of the Science and Technology Policy is the formation of Technology Park Malaysia. Technology Park Malaysia was established in 1988 as an agency under Ministry of Science, Technology, and Environment but later privatised in 1996 (25). One of Technology Park Malaysia's objectives is to provide a platform for technology linkages and knowledge dissemination among research institutes, the financial community, and industries (25). However, the effectiveness of Technology Park in Malaysia in promoting technology transfer are still lacking (26).

\subsubsection{Industrial Master Plan (The late 1980s to 2020)}

The Government of Malaysia has first introduced the Industrial Master Plan late 1980s. The plan covered the period of 1986 to 1995 and focused on the development of the manufacturing sector in the country. The second Industrial Master Plan was formulated after the end of the first Industrial Master Plan and covers the period of 1996 to 2005. The second Industrial Master Plan was formulated with the objectives of strengthening the industrial linkages of the manufacturing sector as well as creating more value added activities for the local manufacturing sector (27). The third Industrial Master Plan was then introduced covering the period from 2006 to 2020. The third Industrial Master Plan was developed and formulated based on the need to create a more competitive manufacturing sector as well as the services sector in the long term (27).

The third Industrial Master Plan recognised the need for local Small and Medium Enterprises to adopt high-level technology to sustain and compete in the market (27). Therefore, the action plan formulated in the Third Industrial Master Plan has become the main driver for local Small and Medium Enterprises to use technology transfer as a mean to compete in the competitive market.

\subsubsection{National Automotive Policy (Late 2000 to cur- rent)}

The National Automotive Policy was first introduced in 2006 as a means to transform the local automotive industry to be more competitive and integrated into the global market (28). The focus of the policy was for the Malaysia's local automotive to have the economic scale, increase industry linkages and at the same time increase their competitiveness through value added activities (28). As the global automotive industry changes over the years, a review of the national automotive policy was conducted in 2014 . One of the main objectives of the revised policy is to promote a strategic collaboration between PROTON with a global Original Equipment Manufacturer company. The partnership is to ensure technology transfer and Research \& Development activities to Malaysia (28)

The technology transfer for the automotive industry in Malaysia is mainly shaped by the two national automotive carmakers, PROTON and PERODUA. However, a study has shown that the key contribution of the local automotive industry is mainly in the development of local vendors and employment creation (29).

\subsubsection{Offset Policy (The late 1980s to 2014)}

The Offset program was initiated early in 1983 as a countertrade program under the Ministry of International Trade and Industry. However, it was only in 1987 that a treasury circular was circulated as a guideline to the implementation of countertrade in government procurement (30). The policy and guidelines were then 
updated to have offset as mandatory requirements in all government procurement and came into effect on 18 March 2011 (30) Based on the treasury circular and subsequently updated to Industrial Collaboration Policy (ICP) in 2014, a mechanism was put in Government procurement that requires a mandatory technology transfer program. Each time a Government procurement above RM50 million is being tendered out, it triggers the requirement for an Offset Program (31).

The concept of Offset Program is that it leverages on Government procurement to obtain technology transfer, market access, research and development in collaboration with the Original Equipment Manufacturer. Through this policy, technology transfer process was planned and monitor closely to ensure the objective of the technology transfer is achieved. The Offset policy has facilitated several different technology transfer model from dissemination model to interrelationship model. Due to the reason the technology transfer is mandatory and act as a requirement to fulfil the contract obligation, there is less mutual trust between transferor and transferee (32).

Table 1 below shows the summary of Government of Malaysia's Policy that directly and indirectly facilitates the technology transfer to the country over the years. The table also includes remarks on the strength and gaps in each of the policy in facilitating technology transfer process.

Table 1: Summary of Related National Policies that Facilitates Technology Transfer

\begin{tabular}{|c|c|c|c|c|c|}
\hline \multirow{2}{*}{ Policy } & \multirow{2}{*}{ Year } & \multicolumn{3}{|c|}{ Focus on Technology Transfer } & \multirow{2}{*}{ Remarks } \\
\hline & & Pre- & Implementation & Post & \\
\hline $\begin{array}{l}\text { Import Substituting } \\
\text { Industrialization (ISI) } \\
\text { Policy }\end{array}$ & Early 1960 s & No & Yes & No & $\begin{array}{l}\text { - Passive role of technology transferor } \\
\text { and transferee } \\
\text { - No mechanism to monitor Technol- } \\
\text { ogy Transfer }\end{array}$ \\
\hline $\begin{array}{l}\text { Export Oriented Indus- } \\
\text { trialization (EOI) Poli- } \\
\text { cy }\end{array}$ & $\begin{array}{c}\text { The Late } 1960 \mathrm{~s} \\
\text { to } 2000\end{array}$ & No & Yes & No & $\begin{array}{l}\text { - Quasi-active role of technology } \\
\text { transferor and transferee } \\
\text { - No mechanism to monitor Technol- } \\
\text { ogy Transfer }\end{array}$ \\
\hline Look East Policy & Early $1980 \mathrm{~s}$ & Yes & Yes & No & $\begin{array}{l}\text { - Quasi-active role of technology } \\
\text { transferor and transferee } \\
\text { - No mechanism to monitor Technol- } \\
\text { ogy Transfer }\end{array}$ \\
\hline $\begin{array}{l}\text { Science \& Technology } \\
\text { Policy }\end{array}$ & $\begin{array}{l}\text { The late } 1980 \text { s to } \\
\text { current }\end{array}$ & Yes & Yes & No & $\begin{array}{l}\text { - Quasi-active role of technology } \\
\text { transferor and transferee } \\
\text { - General mechanism to monitor } \\
\text { Technology Transfer is in place }\end{array}$ \\
\hline $\begin{array}{l}\text { National Automotive } \\
\text { Policy }\end{array}$ & $\begin{array}{l}\text { The late } 1990 \text { s to } \\
\text { current }\end{array}$ & Yes & Yes & No & $\begin{array}{l}\text { - Quasi-active role of technology } \\
\text { transferor and transferee } \\
\text { - No mechanism to monitor Technol- } \\
\text { ogy Transfer }\end{array}$ \\
\hline Offset/ICP Policy & $\begin{array}{l}\text { The late } 1980 \text { s to } \\
\text { current }\end{array}$ & Yes & Yes & Yes & $\begin{array}{l}\text { - Active role of technology transferor } \\
\text { and transferee } \\
\text { - Detail mechanism to monitor Tech- } \\
\text { nology Transfer is in place } \\
\text { - Impact of Technology Transfer is } \\
\text { not measured }\end{array}$ \\
\hline
\end{tabular}

Table 2: Case Study on Technology Transfer in Industries Facilitated by National Policies

\begin{tabular}{|c|c|c|}
\hline Related Policy & Case Study & Transferor \& Transferee \\
\hline $\begin{array}{l}\text { Export-Oriented Indus- } \\
\text { trialization Policy }\end{array}$ & $\begin{array}{l}\text { Technology Transfer to Electrical \& Elec- } \\
\text { tronics (E\&E) Industry } \\
\text { - } \quad \text { E\&E local suppliers in the Free } \\
\text { Trade Zone Areas }\end{array}$ & $\begin{array}{l}\text { Transferor: } \\
\text { Foreign Multinational } \\
\text { Companies } \\
\text { Transferee: } \\
\text { Local E\&E Suppliers in the } \\
\text { Free Trade Zone Areas }\end{array}$ \\
\hline Look East Policy & $\begin{array}{l}\text { Technology Transfer to Automotive In- } \\
\text { dustry } \\
\text { - Assembly of National Car and Local } \\
\text { Supply Chain }\end{array}$ & $\begin{array}{l}\text { Transferor: } \\
\text { Mitsubishi Motor Corpora- } \\
\text { tion } \\
\text { Transferee: } \\
\text { Perusahaan Otomobil Na- } \\
\text { sional Sdn Bhd (PROTON) } \\
\text { \& PROTON's Vendor Sup- } \\
\text { ply Chain }\end{array}$ \\
\hline Offset Policy & $\begin{array}{c}\text { Technology Transfer to Rail Industry } \\
\text { - } \quad \text { Train Assembly Plant for Klang } \\
\text { Valley MRT Line } 1\end{array}$ & $\begin{array}{l}\text { Transferor: } \\
\text { Siemens AG } \\
\text { Transferee: } \\
\text { SMH Rail }\end{array}$ \\
\hline
\end{tabular}

\section{Methodology}

The research method used was through literature review and analysis of national policies that have facilitated technology transfer process in the country as shown in Figure 1. A literature review was also conducted on various frequently used technology transfer model since 1940s and compare it to the technology transfer process evolution in the country. 


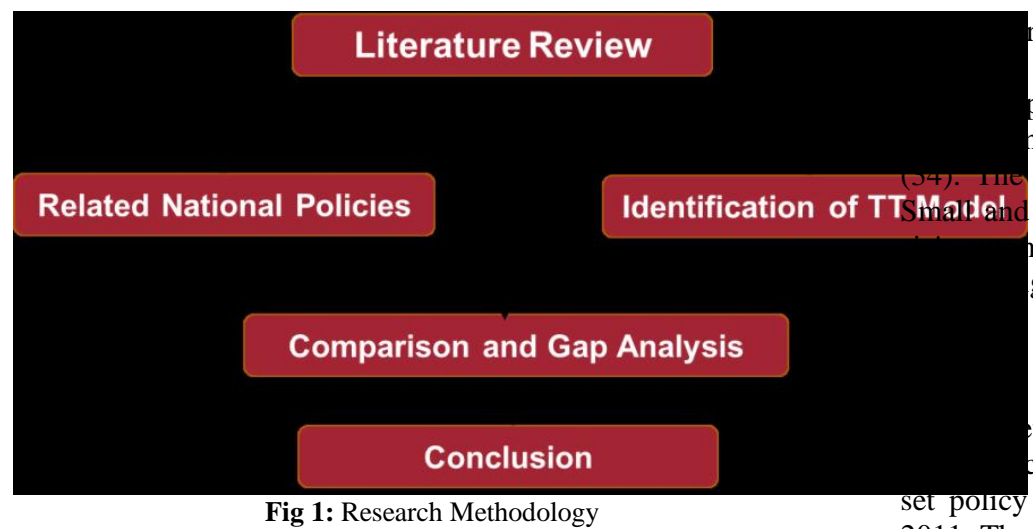

Fig 1: Research Methodology

From the literature review of the related national policies and identification of the technology transfer model, a comparison and gap analysis was further conducted. Based on the time of each specific policy was introduced, selected case studies were chosen for further analysis and review. The comparison was then made according to the type of technology transfer model each selected case studies best represent. Among key indicators used for the review includes whether the transferor and transferee played an active, quasi-active or passive role. Other key indicators are whether there is proper monitoring mechanism or not for each of the case studies that were reviewed. A conclusion was then made based on the findings from the comparison of technology transfer model and gap analysis.

\section{Results and Findings}

The results and findings were based on the review of the case studies, related national policies and the technology transfer model evolution throughout the years. Below are also the comparison, findings, and the current gaps.

\subsection{Case Studies}

Three technology transfer case studies that have occurred as a result of the introduction of specific government's policy have been selected as shown in Table 2. The three case studies represent three different sectors namely; the electrical and electronics industry, automotive industry and the rail industry.

\subsubsection{Electrical and Electronics Industry}

The Export-Oriented Industrialization policy introduced by the government of Malaysia in the late 1960s was further supported by the introduction of the Investment Incentives Act in the 1970s (21). The Act has led to the creation of Free Trade Zones across Malaysia (21). One of the successful Free Trade Zone was located in Bayan Lepas, Penang where most of the Electrical and Electronics industries were located. Free Trade Zone in Penang soon became a hub for semiconductor companies, consumer electronics as well as the hard disk drive industry in the 1980s and 1990s (33). The influx of large and established Multinational companies in the Free Trade Zone have open the supply opportunities for local companies in Penang. The established linkages between the Multinational companies and local Small and Medium Enterprises have helped the local companies to upgrade their products and value added services activities (33).

\subsubsection{Automotive Industry}

Starting from the Look East Policy introduced in the early 1980s, the Malaysian automotive industry has evolved from merely assembling passenger cars to manufacturing automotive parts and components (29). Regarding technology transfer, the automotive industry namely through PROTON have successfully applied the technology received from their Joint Venture partner, Mitsubishi rporation and disseminate it to their local supply chain. at that time also encouraged local vendors to have a $\mathrm{p}$ regarding a joint venture and technical assistance with hese counterparts to speed up their development process joint venture between the foreign company and local Medium Enterprises have further strengthened Malaynotive industry and transform them to be a competent ger manufacturer (29).

\section{Rail Industry}

t policy was introduced in the early 1980s and have cused on countertrade program (30). However, the Offset poricy was revised in 1987 and later were revised again in 2011. The revised policy introduced a proper mechanism to monitor Offset programs in government procurements in a more structured manner. One of the successful technology transfer program triggered by the Offset program is the technology transfer initiatives by Siemens AG to SMH Rail Sdn. Bhd. (35). In this technology transfer project, Siemens AG supervised SMH Rail in the planning and design of the train assembly plant. The program also involved Siemens training local workers and technician to support the operation of the train assembly plant (35). The Klang Valley Mass Rapid Transit Offset program also have other human capital development program involving the training and upgrading the capability of local engineers. The Works Package Contractors that act as the technology providers in the Klang Valley Mass Rapid Transit Offset program are Siemens, Xerox, Bombardier, Meidensha and Mitsubishi Heavy Industries (32).

\subsection{Technology Transfer Model Evolution}

There are many technology transfer model that has been developed throughout the years. These are some of the popular and also most cited technology transfer models during a certain period such as the appropriability model, dissemination model, and knowledge utilisation model to name a few.

Figure 2 below shows the national policies that facilitated technology transfer since the 1940 s and how it relates to certain technology transfer model and its evolution.

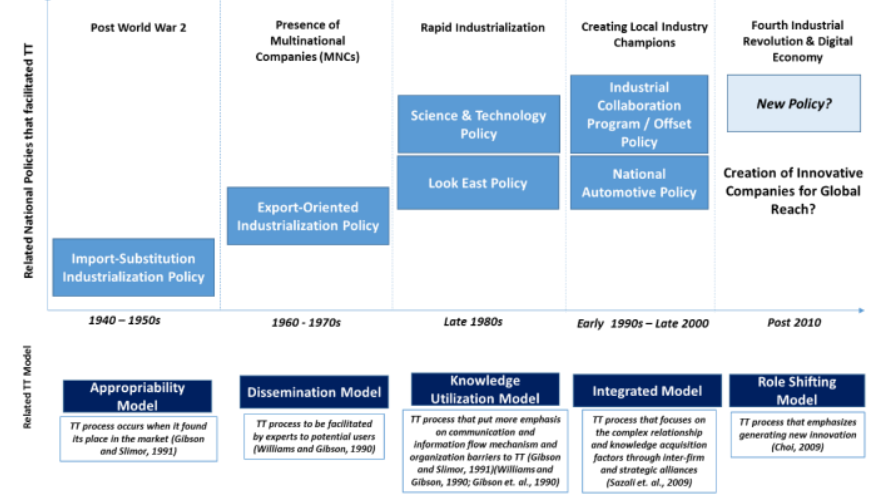

Fig 2: Evaluation of Technology Transfer (TT) Model and the Relation to National Policies

The previous technology transfer model from 1940s to 1970 s emphasised more on the technology itself rather than the transferor and transferee. The appropriability model and dissemination model stated in Gibson and Slimor (12) studies further show this emphasis. The gap in these model is that technology provider and the technology recipient plays a passive and quasi-passive role in the successfulness of the technology transfer. It also relates to the policy of the country at that time that does not emphasise on technology transfer from the foreign company that set their production here. The focus of the Import-Substitution Industrialization policy was to create local employments.

However, by late 1980 s to 2000 , there was a shift of technology transfer model as more emphasis was given on the mechanism of technology transfer flow between the transferor and transferee. 
The knowledge utilisation model and communication model (12, 14) has emphasised the communication as well as potential barriers the recipients have in receiving the technology. This type of model started to look into the factors and sub-factors that influence the technology transfer process.

In the 1990s, as Multinational companies started to set base in many developing countries, technology transfer model started to focus on the complex interrelationship and inter-firm technology acquisition (16). The model emphasised several factors in interfirm knowledge acquisition that have a direct effect on the technology transfer process. When technology becomes more complex, the role shifting model takes prominence as the model focuses more on innovation and not just technology transfer alone (18). Innovation has now become a necessity for companies to survive. Companies now need to absorb technology faster and also be able to innovate and apply the technology faster as well.

\subsection{Current Gaps}

As we are heading towards 2020 and beyond, technology has not just become more complex but becoming obsolete faster than before. The industry is now entering the fourth industrial revolution, and therefore technology development will become more rapid than ever. Therefore, a new technology transfer model is needed to accelerate innovation and also accelerate the technology transfer process before the technology becomes obsolete. As shown in Figure 2, the "Role Shifting Model" is a technology transfer process that emphasises on the creation of innovation instead of just technology transfer (18). Companies nowadays must also have better technology management in place internally in their company's structure. In managing technology, technology companies need to be able to channel the knowledge and technology input that they received from suppliers into the output to client and customers (36).

The current national policy that encourages technology transfer such as the Offset Policy and Industrial Collaboration Program Policy does not encourage innovation to happen between the transferor and transferee. The mechanism and structure in the policy emphasised more on the implementation aspect of technology transfer. Technology transfer and technology development should be used by the local companies as a key driver for business innovation. Further studies show that there are identified links between technology development and the company performance regarding its influence in innovation (37).

Therefore, it can be summarised that the technology transfer process and its link to the performance of the recipient as a business entity still have its gap. The gap can be identified and analysed by studying what are the factors determining the effectiveness of the current technology transfer facilitated by this national policy and identified the support to performance growth of a company.

\section{Conclusion}

Based on the review in this paper, it can be said that national policy does affect the technology transfer process in the country. However, the effectiveness of the technology transfer with regards to each specific policy that was introduced is yet to be measured. Due to the technological landscape that we have currently, technology transfer process needs to take into account the innovation factor as one of its result and impact. The technology transfer model and the process of the current national mega project such as the Klang Valley Mass Rapid Transit project can be used as a benchmark. A Study can be further conducted in measuring the effectiveness of a technology transfer program that was facilitated by a specific policy introduced by the government.

\section{References}

[1] Segman R. Communicating technology: An historical view. The Journal of Technology Transfer. 1989;14(3):46-53.
[2] Cameron EH. Samuel Slater: Father of American Manufacturer. Portland, MA: The Bond Wheelright Company; 1960

[3] Irwin, Moore. Technology Transfer and Communication: Lesson from Silicon Valley. Journal of Information Sciences. 1991;17:273 $-80$.

[4] Mandel A. The Effects of Japanese Culture and History on the Adoption of Quality Control Techniques: Brandeis University; 2012.

[5] Jusoff KA, R A, Z. Takahashi Y. The Japanese Influence in Malaysian Automotive Industry: Human Resources Management and Development Practices. Management Science and Engineering. 2009;3(4).

[6] MIGHT. Malaysian Rail Supporting Industry Roadmap 2030: Malaysian Industry-Government Group for High Technology 2014.

[7] Simkoko EE. Analysis of Factors Impacting Technology Transfer in Construction Projects: Case Studies from Developing Countries. Stockholm: Swedish Council for Building Research, 1989.

[8] Waroonkun T. Modelling International Technology Transfer in Thai Construction Projects: Griffith University; 2007.

[9] Haghirian P, editor Does Culture Really Matter? Cultural Influences on the Knowledge Transfer Process Within Multinational Corporations. Eleventh European Conference on Information Systems; 2003; Naples. Italy.

[10] Chan L, Aldhaban F, editors. Technology Transfer to China: With Case Studies in the High-Speed Rail Industry. PICMET 2009 2009; Oregon, USA.

[11] Akubue AI. Technology Transfer: A Third World Perspective. The Journal of Technology Studies. 2002(28 (1)):14 - 21.

[12] Gibson DV, Smilor W. Key Variables in Technology Transfer: A Field - Study Based on Empirical Analysis. Journal of Engineering and Technology Management. 1991;8:287 - 312.

[13] Jafarieh H. Technoloy Transfer to Developing Countries: A Quantitative Approach: University of Salford; 2001.

[14] Williams F, Gibson DV. Technology Transfer: A Communication Perspective. Newbury Park: Sage Publications, Inc.; 1990

[15] Rogers EM, Takegami S, Yin J. Lessons Learned about Technology Transfer. Technovation. 2001;21 (2001) 253-261.

[16] Sazali AW, Haslinda A, Jegak U, Raduan CR. Evolution and Development of Technology Transfer Models and the Influence of Knowledge-Based View and Organizational Learning on Technology Transfer. Research Journal of International Studies. 2009(12).

[17] Bradley SR, Hayter CS, Link AN. Models and Methods of University Technology Transfer. Greensboro: University of North Carolina; 2013

[18] Choi HJ. Technology Transfer Issues and a New Technology Transfer Model. The Journal of Technology Studies. 2009;35(No. 1).

[19] Jomo KS. Industrializing Malaysia: Policy, Performance, Prospects. Jomo KS, editor. New York: Routledge; 1993. 1 - 13 p.

[20] Osman-Rani, Piei. Malaysia's Industrialization and Trade: Issues, Options and Strategies. Jurnal Ekonomi Malaysia. 1990;21 \& 22:13 $-44$.

[21] Rasiah R. Free Trade Zones and Industrial Development in Malaysia. In: Jomo KS, editor. Industrializing Malaysia: Policy, Performance, Prospects. New York: Routledge; 1993.

[22] Kiong F. The Look East Policy: Its Impact in Promoting Japanese Management Techniques to Manufacturing Firms in Malaysia $[\mathrm{PhD}$ Thesis]: University of Stirling; 2000.

[23] Japan Eo. The Malaysian Look East Policy 2016 [cited 2016]. Embassy of Japan. Available from: http://www.my.embjapan.go.jp/English/JIS/education/LEP.htm.

[24] MOSTI. Dasar Sains, Teknologi dan Inovasi Negara. 2016. p. 1 - 2.

[25] Awang AHA, Hussain MYH, Abdul Malek J. Promoting Knowledge Transfer in Science and Technology: A Case Study of Technology Park Malaysia (TPM). Zagreb: The Institute of Economics, 2008.

[26] Mhd Sharif S, Ismail Y. Technology Parks, Knowledge Transfer and Innovation: the Case of Malaysia's Information and Communication Technology (ICT) Small and Medium Enterprises. International Journal of the Information Systems for Logistics and Management (IJISLM). 2006;1(2):133 - 42.

[27] MITI. Third Industrial Master Plan (IMP3) 2006 - 2020. Ministry of International Trade and Industry Malaysia; 2006.

[28] MITI. Review of National Automotive Policy 2009 [cited 201711 May 2017]. Available from: http://www.miti.gov.my/index.php/pages/view/1449.

[29] Wad P, Govindaraju CVGR. Automotive Industry in Malaysia: An Assessment on its Development. Int J Automotive Technology and Management. 2011;11(2). 
[30] TDA. ICP History and Background 2016 [cited 2016]. Available from: http://tda.my/icp/icp-history-background/.

[31] MOF. Policy and Guidelines on Industry Collaboration Program in Government Procurement. In: Procurement Do, editor. PK 1/2013, Lampiran 1.5 ed: Ministry of Finance Malaysia; 2014.

[32] Hamdan AR. Assessment on the Effectiveness of Technology Transfer in the Klang Valley Mass Rapid Transit (KVMRT) Codesigning Offset Projects: Universiti Teknologi Malaysia; 2015.

[33] Witte I. Evolution of the Automation Industry in Penang 2005 2011: Exception on the National Stagnation? : Utrecht University 2012 .
[34] Rosli M. The Automobile Industry and Performance of Malaysian Auto Production. Journal of Economic Cooperation. 2006;27(1 (2006) 89-114).

[35] Malaysia's train assembly plant gets Siemens acceptance cert [press release]. The Star2015.

[36] Luggen M. Technology and Innovation Management in New Technology-Based Firms: Swiss Federal Institute of Technology Zurich; 2004.

[37] Baden-Fuller C, Haefliger S. Business Model and Technological Innovation. Long Range Planning. 2013;46 424 -5. 